\title{
The Luangwa Valley
}

Mr N. O. J. Abel, Acting Chief Wildlife Research Officer in Zambia, has sent these comments on the Introduction and Postscript to Mary Gough's paper on the Luangwa Valley in Oryx, October 1973.

In an introduction to Mary Gough's paper, The Luangwa Valley: an Ecological Study, in Oryx, October 1973, Dr R. M. Lawton and Miss E. Millward stated that "very little if anything is known about the movements and activities of elephant during the rains, that is, from December to April'. Mr Abel points out that recently the results of year-round ecological studies in the Luangwa Valley have been presented in a 259-page report to the Government of Zambia (Naylor et al. 1973), 'with information on 24 large mammal species, including elephant, comprehensive studies of the commoner species, and detailed descriptions of animal-vegetation interactions'. This was published after the Introduction was written.

Commenting on Dr Lawton's comparison of the Munyamadzi Game Reserve Management Area and the South Luangwa National Park, in the postscript to Mrs Gough's paper, Mr Abel quotes the following figures:

$\begin{array}{lcc}\text { Human density } & \begin{array}{c}\text { Munyamadzi Game } \\ \text { Management Area } \\ \text { c. } 2 / \mathrm{km}^{2}\end{array} & \begin{array}{c}\text { South Luangwa } \\ \text { National Park } \\ \text { effectively zero }\end{array} \\ \begin{array}{l}\text { Elephant density in the } \\ \text { alluvial belt Jan. 1973 }\end{array} & 4.0 / \mathrm{km}^{2} & 7.1 / \mathrm{km}^{2}\end{array}$

Mr Abel writes: 'In the national parks all killing is prohibited, except for research or management, but the game management areas, which are often "buffer zones" around the national parks, contain varying densities of resident humans who practise shifting cultivation and subsistence hunting; some safari hunting is also permitted. In these areas the department's policy is to permit a sustained-yield offtake of animals. Densities of the commoner animals in the Luangwa game management areas lie at about 70 per cent of the densities in the South Luangwa National Park (Naylor et al. 1973)

'The Department and the UN/FAO Luangwa Valley Conservation and Development Project have been concerned about gross vegetation changes occurring within the Luangwa National Parks. Like Dr Lawton, they have not detected such changes in the Munyamadzi Game Management Area, but unlike Dr Lawton we feel it would be unwise to base park management on data collected in a game management area where there is a steady hunting pressure by humans, and where animal densities are lower than in the national parks. Dr Lawton was unable to detect changes in tree canopy cover in the South Luangwa National Park from the aerial photographs, but W. L. Astle's (1971) evidence is supported by an extensive system of plots and fixed-point photographs.

'The elephant population of the North Luangwa National Park, which Dr Lawton believes is small at the moment, is in fact estimated 
at 17,700 animals, with a standard error of 3,510 (Naylor et al. 1973). The North Luangwa population seems to be slightly denser than that of the South National Park: $3.97 / \mathrm{km}^{2}$ as against $3.35 / \mathrm{km}^{2}$.

'So far all cropping has been either for management or research purposes, as explained by Astle (1971). The hippo cropping programme was an experimental scheme, in a $16-\mathrm{km}$. stretch of the Luangwa River, to examine the effects of reduced hippo density on the riverine grasslands, as a result of which it was decided that there was no ecological reason for a capital reduction of the population of c.14,000 animals. Incidentally, control of the abattoir, which is situated outside, not in, the South Luangwa National Park, has now reverted to the Department and no cropping has occurred since 1972.'

\section{References}

ASTLE, W.L. 1971. Management in the Luangwa Valley. Oryx XI, 2-3, September 1971.

GOUGH, M. 1973. The Luangwa Valley: an Ecological Study. Oryx XII, 2. October, 1973.

LAWTON, R.M. and GOUGH, M., 1970. Elephants or Fire-which to blame? Oryx X, 4. May, 1970.

LAWTON, R.M. 1970. Destruction or Utilisation of a Wildlife Habitat? in the Scientific Management of Animal and Plant Communities for Conservation. 11th Symposium, British Ecological Society, Blackwell.

NAYLOR, J.N., CAUGHLEY, G.J., ABEL, N.O.J., and LIBERG, O., 1973. Game Management and Habitat Manipulation. FO:DP/ZAM/68/510 Working Document No. 1. UNDP, FAO, Rome 1973.

\section{Brief Reviews}

Although only 35 species of tree are native to the British Isles, no fewer than 1700 can be found in parks, botanic gardens and private arboreta (and even this omits many subtropical specialities in Tresco and a few other treasure houses). This is the field explored by Alan Mitchell in his superb Field Guide to the Trees of Britain and Northern Europe (Collins, £2.95), and he covers all Europe north of the Mediterranean. The fine array of colour and black and white illustrations enormously simplify the identification problem, whose solution is the book's main aim. It thoroughly deserves its great success.

The Provisional Atlas of the Amphibians and Reptiles of the British Isles, edited by Henry R. Arnold for the Biological Records Centre at Monks Wood (Classey, Faringdon, Oxon, 25p), consists of dot distribution of our six native and two introduced (edible and marsh frogs) amphibians, and six native reptiles. Ireland is included, for despite St Patrick it has natterjack toads, smooth newts and common lizards, as well as the introduced common frog.

Protection of Man's Natural Environment, published in Warsaw by the Polish Academy of Sciences, a large work of over 660 pages in the English translation, was initiated and planned by Wladyslaw Szafer, a former Chairman of the IUCN Commission on National Parks, who died in 1970. Contributions from over 30 Polish scientists cover all aspects of nature conservation as a basis for preserving the environment and its resources, concluding with a 40-page survey of world national parks and a 30 page account of Poland's national parks, protected sites and monuments. 